\title{
The nature of deep-marine sedimentation and palaeocurrent trends as evidence of Pindos foreland basin fill conditions
}

\author{
University of Patras, Department of Geology, Sedimentology Laboratory, 26500 Patras, Greece.
}

\begin{abstract}
The Pindos foreland basin is an example of Tertiary turbidite basin fill, segmented during its evolution by propagating thrusts. The distribution of turbidite facies in the Pindos foreland and the palaeocurrent directions of submarine fan development show that the northern part of the Pindos foredeep, from the middle Eocene to the late Oligocene, was an example of underfilled foreland basin. Adjacent to the Pindos thrust front (internal Ionian zone), during that period, in the northern part of the thrust, a valley was formed in which sediments concentrated from both the thrust front and the peripheral bulge. As a result of underfilled conditions, coarsegrained conglomeratic deposits accumulated only in the internal Ionian zone (proximal part-inner fan deposits) while in the middle Ionian zone medium-grained sediments were deposited (distal part-outer fan and basin plain deposits) without any presence of conglomeratic distributary channels. The restriction of the coarsegrained deposits in the internal Ionian zone and the basin underfilled conditions are related to the Pindos foreland evolution, and especially to the internal thrusting and intrabasinal high. It seems that the underfilled conditions could be related to narrow linear foreland basins where deep-water submarine fans accumulated.
\end{abstract}

\section{Introduction}

The ultimate controls on the type and pattern of submarine fan sedimentation in a foreland basin are tectonics, climate and eustatic sea level changes. The main parameter which reflects the influences of the above three factors and can be observed in an ancient system is the grain size. Moreover, the grain size is closely related to the source area and to the type of the feeder system.

The first attempts to classify ancient submarine fan deposits were made by Walker $(1965 ; 1978)$ and Mutti and Ricci Lucchi (1972), whose models description was based on a fan which was fed by a single feeder channel. In those models the feeder channel was split downcurrent into distributary channels, and gave to the fan a radial form. Although this classical fan model is widely accepted, there are researchers who are critical of the Mutti-Ricci Luchi scheme, and propose models which correlate the dispersal patterns with tectonic, global fluctuation in sea level change and drainage area (for review see Shanmugam, 2000). Depositional systems in deep-water basins have been classified on the basis of grain size and feeder system by Reading and Richards (1994) into 12 classes.
In their classification, Reading and Richards (1994), outside the grain size (fine-grained and coarse-grained systems), took into account a second factor, which was the nature of the feeder system, proposing: (a) a single point source and (b) a multiple feeder system type. Based on the conditions in which a foreland basin is filled, Jordan (1995) proposed two types of foreland basin fill, the underfilled and the overfilled basins. An underfilled foreland basin is characterized by the formation of a valley which receives sediments from both the thrust belt and the peripheral bulge. An overfilled basin receives sediments from the thrust front, and the sediment supply may exceed subsidence.

The purpose of the present paper is to estimate the Pindos foreland basin fill conditions, in northwestern Greece, correlating the feeder system and the submarine fan dispersal patterns with the tectonic regime of external Hellenides.

\section{Pindos foreland basin}

The Pindos foreland basin developed in the external Hellenides during the late Cretaceous and early Tertiary (Underhill, 1989), and comprises the Gavrovo and Ionian geotectonic zones (Aubouin, 1965) (Figures 1a,b). According to Underhill (1985) and Clews (1989), the subsidence was the result of lithospheric flexure, associated with thrust sheet loading, which took place in front of the Pindos thrust, during the late Eocene to Oligocene. According to Avramidis et al. (2000a), the Pindos foreland, in the northern part, changed to a broken type foreland basin during the late Oligocene to early Miocene, while southwards changed to a piggy-back basin in the early Pliocene (Zelilidis et al., 1998).

The Pindos foredeep during the middle Eocene to late Miocene (Avramidis, 1999) was filled by submarine fan deposits (Pavlopoulos, 1983; Alexander et al, 1990; Leigh and Hartley 1992; Avramidis et al., 2000a), and the source material of the submarine fans was the Pindos mountains (Piper et al., 1978; Faulp et al., 1998). Tectonically, submarine fans developed during the westward progradation of the external Hellinides, and their deposits now extend longitudinally to the axes of the major Epirus synclines, Botzara (middle Ionian zone) and Epirus-Akarnania (internal Ionian zone) (IGSR and IFP, 1966) (Figure 1a). Submarine fan sedimentation was influenced mostly by regional tectonic activity, and to a lesser extent by eustatic sea level changes (Avramidis et al., 2000b). Moreover, differential distribution of submarine fan facies, from north to south, reflects the differential activity of the Pindos thrust (Fytrolakis and Antoniou, 1998; Avramidis et al., 2000).

Palaeocurrent data for the submarine fan development of the Pindos foreland basin have been produced by Richter (1976); Piper et al., (1978); Clews (1989); Alexander et al. (1990); Leigh (1991); Wilpshaar (1995); Bonorino (1996), and Avramidis and Kontopoulos (1998). 

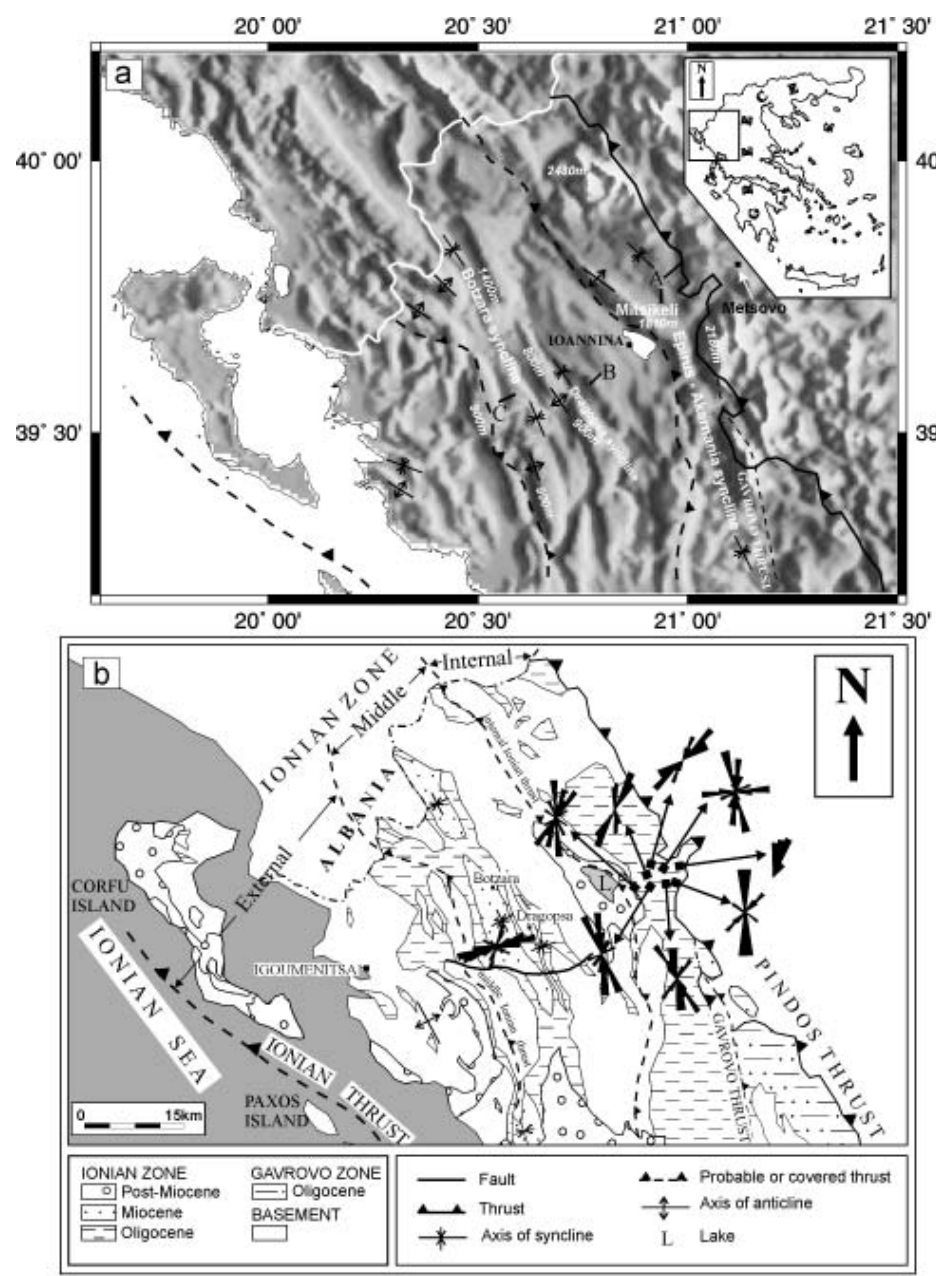

Figure 1 (a) Topographic map of northwestern Greece, showing the major tectonic structures and the locations of the cross-sections $A-A$ ', B-B', C-C'and location (1); (b) Simplified geological map of northwestern Greece. Roses diagrams were made by measurements of sole marks and from data of previous studies such as Leigh (1991), Gonzalez-Bonorino (1996) and Avramidis and Kontopoulos (1998). Palaeocurrent measurements are referred to middle Eocene to late Oligocene turbidites.

\section{Depositional environments}

In order to study the depositional environments and the basin fill conditions of the Pindos foreland, in the present paper we focus on the internal and middle Ionian zone deposits (Figures 1a,b). These parts of the Pindos foreland have a stratigraphic thickness of early-middle Eocene to late Oligocene deposits, up to $6000 \mathrm{~m}$ and $1200 \mathrm{~m}$ respectively, while the external Ionian zone deposits are poorly exposed and reach a maximum stratigraphic thickness of up to $200 \mathrm{~m}$ (IGSR \& IFP, 1966). The turbidite deposits in the internal Ionian zone were examined in cross-section A-A' and in location (1), while in the middle Ionian zone in cross-sections B-B' and C-C' (Figure 1a).

\section{Internal Ionian zone}

Turbidite sedimentation in the internal Ionian zone took place from the early-middle Eocene to the early Oligocene. The thickness of turbidite deposits varies from $1700 \mathrm{~m}$ (Wilpshaar, 1995) to $6000 \mathrm{~m}$ (I.G.S.R and I.F.P, 1966), and these thickness variations are related to the differential activity of the Pindos thrust, from north to south. As the tectonic regime during that period can be described by a westward prograding thrust, the oldest sediments of the internal Ionian zone are now buried under the Pindos thrust and can't be exposed adjacent to the thrust front. The turbidites in the internal Ionian zone are interpreted mostly as inner fan deposits, representing the proximal part of the fan. Sediments in this part of the basin have been examined in the cross-section A-A' and in location (1) on the national road from Ioannina to Metsovo (Figure 1a).

In the examined cross-section A-A' the stratigraphic thickness of turbidites is up to $2400 \mathrm{~m}$ with an estimated age of earlymiddle Eocene to early Oligocene (Figure 2a). The sediments of the cross-section from the bottom upwards consist of early to middle Eocene outer fan deposits (up to $200 \mathrm{~m}$ ) and from middle Eocene to early Oligocene inner fan deposits (up to $2200 \mathrm{~m}$ ) (Figure $2 \mathrm{a}$ ).

The outer fan deposits consist of sandstone/mudstone alter$39^{\circ} 30^{\prime}$ nations characterized by thickening and coarsening upward cycles of sandstone beds up to $7 \mathrm{~m}$, with a s:m ratio of $1: 2$ at the lower part of each cycle, passing upward to 5:1, representing sandstone lobes (Figure 3). These lobes, as a depositional event, are contemporary and can be correlated with the early Eocene inner fan deposits which are now buried under the Pindos thrust. These sandstone lobes, as their age indicates, developed in the primary stage of the formation of the Pindos foredeep in early to middle Eocene times.

Inner fan deposits are the main characteristic of the internal Ionian zone sediments. In cross-section A-A' the inner fan is characterized by interchannel deposits. Interchannel deposits are presented by medium-grained sandstone and fine-grained mudstone alternations with the $\mathrm{s}: \mathrm{m}$ ratio ranging from 1:1 to 2:1 (Figure 4). Moreover, interchannel deposits are presented by alternated finegrained and thin-bedded mudstone and siltstone beds, and in some places medium-grained sandstone beds are intercalated. Westward of the studied cross-section A-A', in locations (1) channel-fill and slumped deposits have been observed (Figure 5). Channel fill deposits are representing by normal graded conglomerate bodies up to $7 \mathrm{~m}$ thick and represent the proximal part of the feeder system. The conglomerate bodies are poorly sorted and clast- or matrix-supported, where the matrix is dominantly sand, and consists of rounded clasts of limestone (40-50\%), basal (25-35\%), sandstone $(0-10 \%)$ and chert $(0-5 \%)$ (Figure 5). Clast sizes range from $5 \mathrm{~cm}$ up to $50 \mathrm{~cm}$ long axis. Some matrix supported conglomerates have been interpreted by Leigh and Hartley (1992) as mega debris flow deposits. Slumps and slides are common and presented by disturbed sediments, chaotic bedding, sandstone and mudstone clasts, and overturned lobe deposits (reverse Bouma (a)
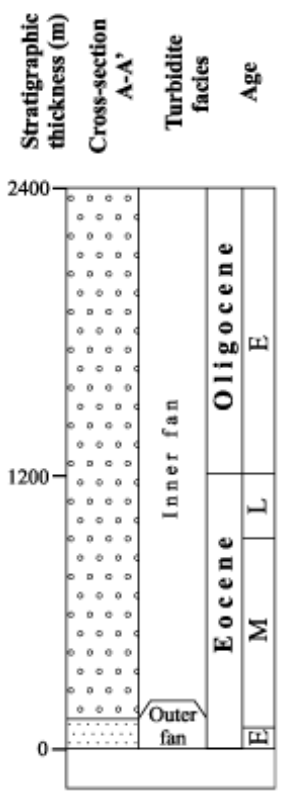

(b)
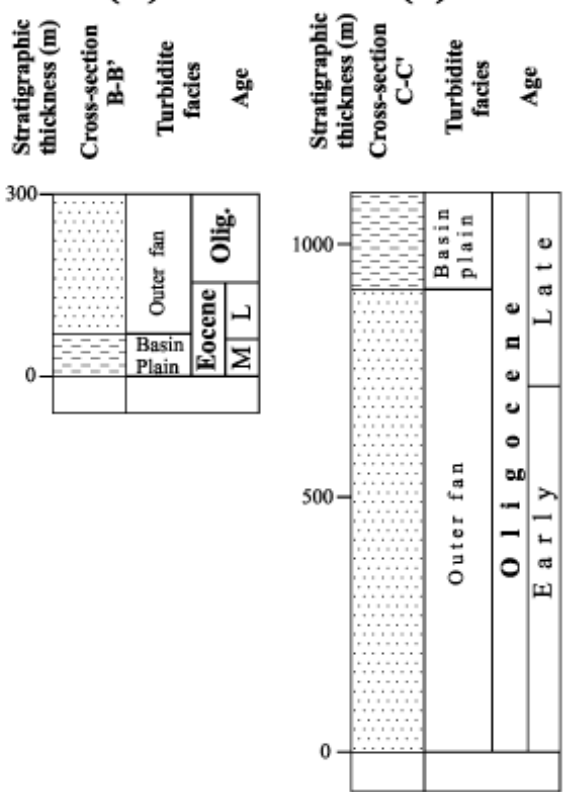

Figure 2 Composite stratigraphic cross-sections and turbidite facies for (a) internal Ionian, cross-section $A-A^{\prime} ;$ (b) cross-section $B$-B'; and (c) cross-section $C$ - $C^{\prime}$ of middle Ionian zone. 
sequence). The age of the slumped lobe deposits is estimated as late Eocene. Moreover, inside the slump horizons coal fragments have been observed. The coal fragments, in combination with the small well rounded clasts, which have been interpreted by Leigh and Hartley (1992) as resedimented beach or fan delta environment, indicate redistribution events within the basin, which were caused either by turbidity currents or by slumps and slides.

\section{Middle Ionian zone}

The turbidites in the middle Ionian zone were accumulated from the middle Eocene to the late Miocene. The middle Eocene-late Oligocene turbidites, on which this paper is focused, range from fine- to medium-grained, and were deposited before the division of the Pindos foreland, which took place in late Oligocene-early Miocene times (Avramidis et al., 2000a).

The major stratigraphic thickness of turbidites in the middle Ionian zone is represented in the Klematia-Paramythia basin (Figure 1b). The Klematia-Paramythia basin involves the Botsara and Dragopsa synclines (Figure 1b). The middle Eocene to late Oligocene turbidites, in this basin, have a composite stratigraphic thickness up to $1200 \mathrm{~m}$. The sediments of the basin were studied in cross-sections B-B' and C-C' (Figures 2b,c), while the sub-environment distribution of the basin has been described by Avramidis (1999). On the basis of lithology, bed thickness, sandstone/mudstone ratio and internal structures, the turbidites of the middle Ionian zone represent the distal part of the submarine fans and are interpreted as the (a) outer fan and (b) basin plain deposits (Walker and Mutti, 1973; Ricci Lucchi, 1975; Mutti, 1977).

(a) The outer fan deposits cover the largest part of the Botsara and Dragopsa synclines. The outer fan deposits in the eastern (up to $400 \mathrm{~m}$ ) and western (up to $900 \mathrm{~m}$ thick) part of the basin are con-

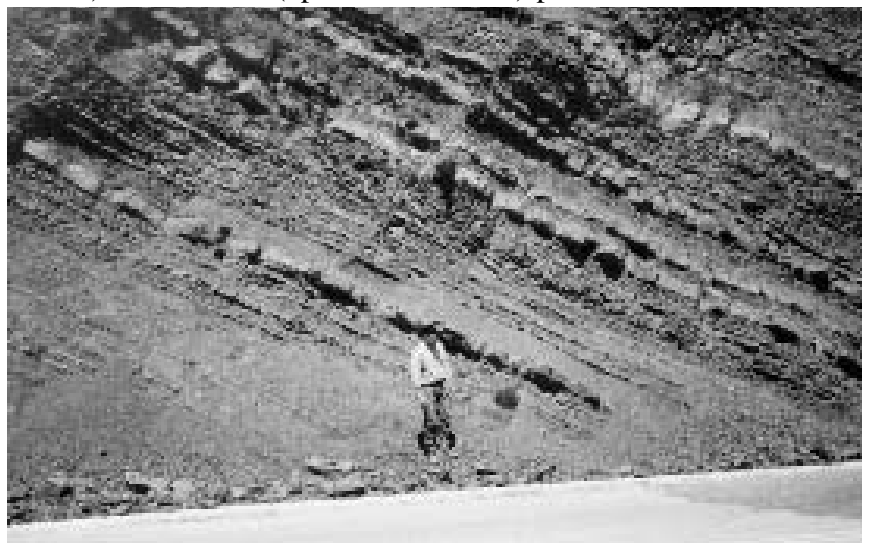

Figure 3 Thickening and coarsening cycle up to $7 m$ thick representing sandstone lobe deposits of internal Ionian zone.

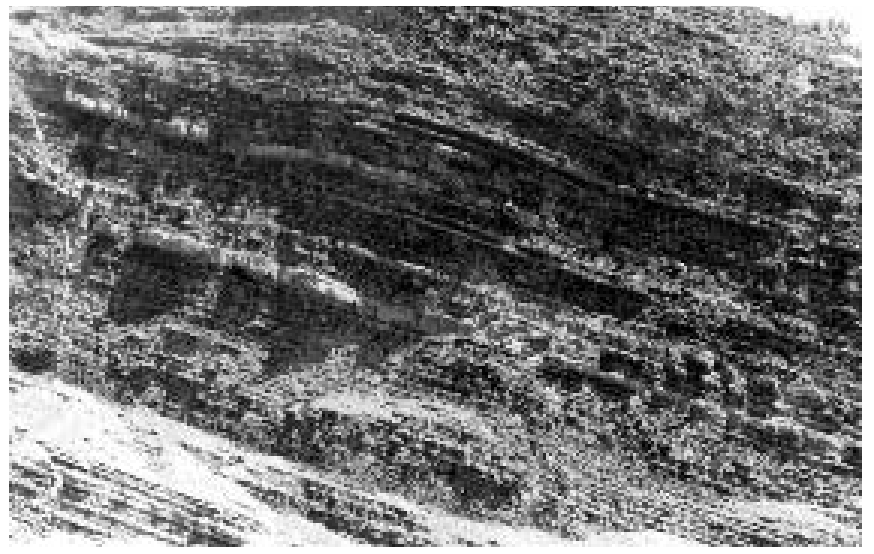

Figure 4 Interchannel deposits, observed in cross-section A-A' of internal Ionian zone. formably overly Eocene limestone, while in the Dragopsa syncline (up to $500 \mathrm{~m}$ thick) they are conformably overly middle Eocene basin plain deposits (Figure 2b). The outer fan deposits consist of thickening- and coarsening- upward cycles (up to $8 \mathrm{~m}$ thick) of sandstone beds, with an increasing s:m ratio from 1:1 at the lower part of each cycle, to $6: 1$ at the upper parts. These thickening- and coarsening- upward cycles represent sandstone lobes. Moreover, within the sandstone lobes cycles (up to $7 \mathrm{~m}$ thick) are intercalated, consisting of medium interbedded sandstone and greyish mudstone beds and having an s:m ratio $1: 1$ to $2: 1$. These cycles are interpreted as lobefringe deposits. Both sandstone lobes and lobe-fringe deposits compose the outer fan which represents the distal part of the fan.

(b) Basin plain deposits have been observed in both the Dragopsa and Botsara synclines (Figure 2b,6). In the Dragopsa syncline are conformably the Eocene limestones which have a stratigraphic thickness up to $50 \mathrm{~m}$. In the Botsara syncline, basin plain deposits are conformably over the outer fan deposits, and have a stratigraphic thickness up to $150 \mathrm{~m}$. Basin plain deposits consist of fissile greyish laminated interbedded mudstone beds with lateral continuity and thin- to medium-bedded sandstone intercalations.

\section{Palaeocurrent trends}

The palaeoflow trends of the submarine fan development in the northern part of Pindos foreland have been studied by Leigh, (1991), Wilpshaar (1995), Gonzalez-Bonorino (1996) and Avramidis and Kontopoulos (1998). In the present paper, in order to estimate the palaeoflow trends and the foreland basin fill conditions, additional to our measurements, previous works are apposed and will be consider as well.

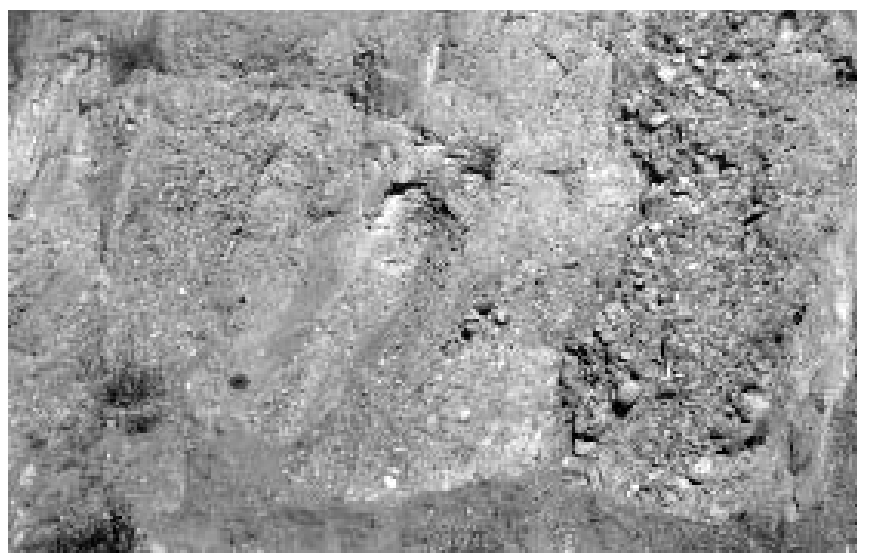

Figure 5 Coarse-grained conglomeratic deposits representing channel fill deposits of inner fan, observed in location (1) of internal Ionian zone.

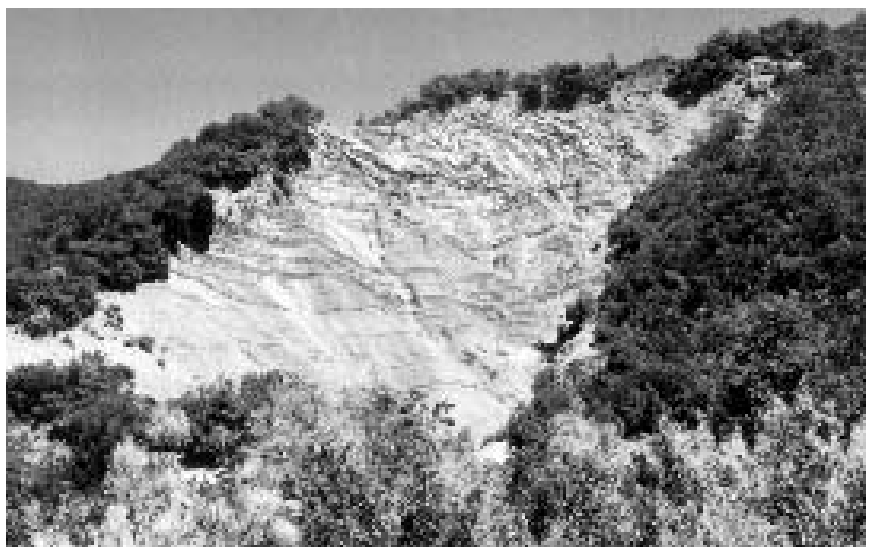

Figure 6 Interbedded mudstone representing basin plain deposits, cross-section $C-C^{\prime}$ of middle Ionian zone. 
The estimation of the flow trends was derived from erosional structures such as sole marks, which are usually observed in the bases of the coarser beds in interbedded turbiditic sequences. In the internal Ionian zone, submarine fans were developed in two major directions. The first direction of submarine fan development was almost north to south and parallel to the Pindos thrust (Figure 1b). The second major direction was north to northeast and in some locations was almost perpendicular to the Pindos thrust (Figure 1b). In the middle Ionian zone the palaeoflow trends of the submarine fan, from the middle Eocene to the late Oligocene, indicate one major direction east-northeast to west-southwest (Figure 1b).

The palaeoflow trends indicate that the source material in the internal Ionian basin was derived both from the Pindos Mountains (suggesting a north to northeast direction) and from the northern or southern ends of the basin (suggesting a north to south direction). In the middle Ionian zone the major sediment input was east-northeast, indicating that the development of the submarine fans was parallel to the westward progradation of the Hellenide orogene.

\section{Basin fill conditions}

In the present paper, and for the proposed basin fill model (Figure 7), we are taking into account the grain size distribution of the submarine fan (coarse and fine grained turbidites), the palaeocurent directions and the basin floor topography, which is an important factor, controlling the turbidity current pathways.

The internal Ionian zone deposits are characterized by the existence of conglomaretic deposits which have been interpreted by Leigh and Hartley (1992) as mega debris flow deposits and by slump horizons as interpreted by Avramidis et al. (2000b). The existence of conglomerates and slumps indicates that the internal Ionian zone was the proximal part of the Pindos foreland basin, and the main feeder systems for the whole basin developed there. Although coarse-grained sediments are abundant in the internal Ionian zone, in the middle Ionian zone they are absent, representing the distal part of the Pindos foredeep (Avramidis et al., 2000a). This indicates that the major feeder systems (canyons and channels-a point source near Metsovo) were restricted in the internal Ionian zone, and the middle Ionian zone was fed by minor entry points, where the finer material accumulated. This assumption that the major entry point of sediments was near Metsovo presupposes that east of Metsovo and in the Pindos mountains there existed a well-developed drainage system, which supplied the foredeep with sediments (Figure 7).

Restriction of the main feeder channels in the internal Ionian zone might have occurred, if the transport process was too inefficient and the sediment supply did not exceed subsidence, or an intrabasi-

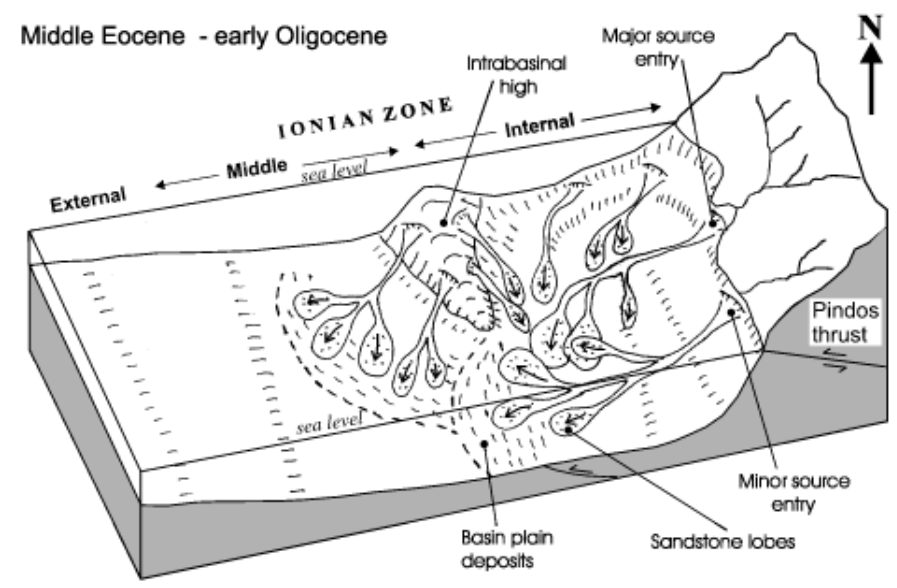

Figure 7 Block diagram modeling the distribution of submarine fans in Pindos foreland basin from early-middle Eocene to early Oligocene. nal high did not leave coarse-grained sediments via submarine channels to accumulate in the middle Ionian zone. In combination with the palaeocurrent trends for the internal Ionian zone, which are parallel to the Pindos thrust, this suggests that the feeder systems could not cross the topographic high of Mitsikeli. The Mitsikeli high formed as a ramp anticline which separated the internal and middle Ionian zone and controlled the turbidite distribution (Figure 7). As a result, the current pathways were not only westwards, from the Pindos thrust front, but switched laterally, suggesting a north to south direction. The palaeocurrent trends for the middle Ionian zone indicate that the submarine fan development was parallel to the westward progradation of the external Hellenides. This indicates that the feed of the middle Ionian zone was made by isolated minor channels and canyons which overlapped the Mitsikeli high or from southern minor feeders that were not restricted by the topographic high (Figure 7).

The above assumption indicates that within the Pindos foreland, during the Eocene, narrow linear subbasins were formed, due to intrabasinal basement highs or internal thrusting. Examples of worldwide narrow linear foreland basins filled by deep-water submarine fans deposits are the Alberta foreland basin (Cant \& Stockmal, 1993), Alpine foreland and Mesohellenic basin (Zellilidis, 1997).

\section{Underfilled foreland basin}

During the middle Eocene to late Oligocene, the internal Ionian zone was fed by a main sediment entry now located near Metsovo village and by a northern peripheral bulge, and coarse-grained sediments accumulated, while the middle Ionian zone was fed by a minor feeder system and finer material accumulated (Figure 7). The minor feeder canyons which fed the middle Ionian zone were located south of the major entry point, and their development was not restricted by the intrabasinal high. Another possible feed was some isolated canyons which eroded the underlying turbiditic sediments and resedimented them in the middle Ionian zone (Figure 7). These basin fill conditions indicate that the Pindos foreland, in the northern part, is an example of an underfilled foreland basin with a multiply feeder system, which is characterized by a major entry point source near Metsovo and by minor feeder systems located north and south of the above area. According to Jordan (1995), the underfilled conditions are ensured by (a) the axial transport of sediments in the internal Ionian zone, as this is reflected in the palaeocurrent data, and (b) the asymmetric stratigraphic thickness between the internal Ionian zone (proximal part-thickness $>2400 \mathrm{~m}$ ) and the middle Ionian zone (distal part-thickness $1200 \mathrm{~m}$ ).

These basin fill conditions were controlled by the internal thrusting and especially by a new frontal thrust (internal Ionian thrust-produced Mitsikeli high), almost $15 \mathrm{~km}$ west of the major Pindos thrust, that formed the internal Ionian zone basin margin. Due to the activation of the internal thrusts, the basin configuration changed and linear narrow sub-basins started to form. As the new thrust advanced, the major sediments which were derived from the northern and eastern part of Pindos Mountains were restricted within the internal Ionian zone. The proximal submarine fan deposits were folded or deformed even while sediments continued to accumulate above the growing high of Mitsikeli. As a result of the growing of an intrabasinal high, the more distal part of the foredeep (middle Ionian zone) was fed by resedimented turbidites, the development off which was caused by the activation of the internal thrust (Figure 7).

\section{Conclusions}

The Pindos foreland basin from the middle Eocene to the late Oligocene was an underfilled basin which received sediment from both the thrust front and the peripheral bulge. The distribution of the grain size in the internal and middle Ionian zone clearly indicates the proximal and the distal part of the Pindos foredeep, and suggests a multiple feeder system. The feeder system for the Pindos foredeep can be described by a major entry point of coarse-grained sediments 
near Metsovo village and by minor canyons and channels which were developed: (a) south of Metsovo village and (b) from the Mitsikeli high resedimenting the primary turbidites of the Pindos foredeep. The activity of Mitsikeli synsedimentary high is shown by the localized restricted conglomerates and by axial palaeocurrent flow trends adjacent to the Pindos thrust. Moreover, it seems that we can relate the proposed underfilled conditions to the basin configuration, which gradually changed from a wide foreland to linear narrow subbasins, formed internally to the main foreland basin. Underfilled conditions occurred in the first stages of internal subdivision.

\section{References}

Aubouin, J., 1965, Geosynclines. Elsevier, Amsterdam.

Alexander, J., Nichols, G. J., and Leigh, S., 1990, The origins of marine conglomerates in the Pindus foreland basin, Greece. Sedimentary Geology, $66,243-254$.

Avramidis, P., 1999, Depositional environments and hydrocarbon potential of Tertiary formations in Klematia-Paramythia basin, Epirus. Unpubl. doctoral dissertation, University of Patras, 165pp.

Avramidis, P., and Kontopoulos, N., 1998, Hydraulic determination and palaeoflow trends of turbidite deposits in Klematia - Paramythia basin. Bulletin Geological Society of Greece, XXXII, (2), 299-307.

Avramidis P., Zelilidis A., and Kontopoulos N., 2000a, Thrust dissection control of deep-water clastic dispersal patterns in the KlematiaParamythia foreland basin, western Greece. Geological Magazine, 137, pp.667-685.

Avramidis P., Zelilidis A., Vakalas I., and Kontopoulos N., 2000b, Interaction between tectonic activity, eustatic sea-level changes and basin configuration of the Pindos foreland and Mesohellenic piggy-back basins, central Greece. IAS 20th Regional European Meeting of Sedimentology, 5.

Cant, D.J., and Stockmal, G. S., 1993, Some controls on sedimentary sequences in foreland basins: examples from the Alberta Basin. in L.E. Frostick, and R.J. Steel, eds, Tectonic controls and signatures in sedimentary successions. Special Publication IAS, 20, 49-65.

Clews, J., 1989, Structural controls on basin evolution: Neogene to Quaternary of the Ionian zone of western Greece. Journal of the Geological Society, London, 146, 447-457.

Faupl, P., Pavlopoulos A., and Migiros, G., 1998, On the provenance of flysch deposits in the External Hellenides of mainland Greece: results from heavy mineral studies. Geological Magazine, 135 (3), 412-442.

Fytrolakis, N., and Antoniou, M., 1998, Contribution to the knowledge of the Gavrovou subzone flysch formations, in the Messenia and in the area of the Klokova and Varasova mountains, Bulletin Geological Society of Greece, XXXII/1, 23-31.

Gonzalez-Bonorino, G., 1996, Foreland sedimentation and plate interaction during closure of the Tethys ocean (Tertiary; Hellenides; Western continental Greece. Journal of Sedimentary Research, 66, 6, 1148-1155.

Jordan, T. E., 1995, Retroarc foreland and related basins. In: Tectonics of sedimentary basins (Busby J. and Ingersoll R. V. eds.), pp.331-362, Blackwell Science.

Institute for Geology Subsurface Research of Greece and Institute Francais de Pétrole, 1966, Etude geologİque de l' Epire. Technip, Paris, 306pp.

Pavlos Avramidis, received a B.Sc. degree in Geology in 1995 and his Ph.D. in Petroleum Sedimentology from the University of Patras in 1999. His research activities have concentrated on Petroleum Sedimentology, Stratigraphy and Sedimentary Basin Analysis of external Hellenides. He participated in several research projects concerning clastic sedimentology and organic geochemistry. At present he is a post-doctoral fellow of the Greek National Foundation for Scholarships and his research focuses on hydrocarbon potential of foreland and piggy-back basins in Greece.
Leigh S., 1991, Sedimentary evolution of the Pindos foreland basin western Greece. Unpub. Doctoral dissertation, Univ. Wales, Cardiff, 181pp.

Leigh S., and Hartley A.J., 1992, Mega debris flow deposits from the OligoMiocene Pindos foreland basin, western mainland Greece: implication for transport mechanisms in ancient deep marine basins. Sedimentology, 39, 1003-1012.

Mutti, E., 1977. Distinctive thin-bedded turbidite facies and related depositional environments in the Eocene Hecho Group (south-central Pyrenees, Spain). Sedimentology, 24, 107-131.

Mutti, E. and Ricci Lucchi, F., 1972, Turbidites of the northern Apennines; introduction to facies analysis. (Translated into English by T. H. Nilsen 1978). International Geological Review 20, 125-166.

Pavlopoulos A. 1983. Contribution to the study of the flysch of the Makrynoros area Akarnania, Greece. Unpub. doctoral dissertation, Aristotle Univ. of Thessaloniki.

Piper, D. J. W., Panagos, A. G., and Pe, G. G., 1978, Conglomeratic Miocene flysch, western Greece. Journal Sedimentary Petrology, 48 (1), 117-126.

Reading, H. G., and Richards, M., 1994, Turbidite systems in deep water basin margins classified by grain size and feeder system. Bulletin American Association Petroleum Geologist, 78, 792-822.

Ricci Lucchi, F., 1975, Depositional cycles in two turbidite formations of northern Apennines (Italy). Journal Sedimentary Petrology 45, 3-43.

Richter D., 1976, Die flyschozen Grichenlands III. Flysch sowie spät- und postorogen derien in west Griechenland zwischen Albanien und dem golf von Patras. Neues Jahrbuch für Geologie und Paläontologie, Abhandlungen $151,224-252$.

Shanmugam, G., 2000, 50 years of the turbidite paradigm (1950s-1990s): deep-water processes and facies models-a critical perspective. Marine and Petroleum Geology 17, 285-342.

Underhill, J. R., 1985, Neogene and quaternary tectonics and sedimentation in Western Greece. Unpub. doctoral thesis, University of Wales, Cardiff.

Underhill, J. R., 1989, Late Cenozoic deformation of the Hellenide foreland, western Greece. Geological Society of American Bulletin 101, 613-634.

Walker, R. G., 1965, The origin and significance of the internal sedimentary structures of turbidites. Proceedings of the Yorkshire Geological Society $35,1-32$.

Walker, R. G., 1978, Deep water sandstone facies and ancient submarine fans: models for exploration for stratigraphic traps. American Association of Petroleum Geologist Bulletin, 62, 932-966.

Walker, R. G., and Mutti, E., 1973, Turbidite facies and facies associations. In Turbidites and Deep-Water Sedimentation (eds G. V Middleton and A. H. Bouma), pp.119-157, Pacific Section Society of Economic Paleontologists and Mineralogists, Los Angeles, Calif.

Wilpshaar M., 1995, Applicability of dinoflagellate cyst stratigraphy to the analyses of passive and active tectonic settings. Geologica Ultraectina, 134, 132pp.

Zelilidis A., 1997, The impact of basin configuration on coarse grained deposits geometry and turbiditic deposits. IAS 18th Regional European Meeting of Sedimentology, 371-372.

Zelilidis, A., Kontopoulos, N., Avramidis, P., and Piper D. J. W., 1998, Tectonic and sedimentological evolution of the Pliocene-Quaternary basins of Zakynthos island, Greece: Case study of the transition from compressional to extensional tectonics. Basin Research, 10, (4), 393-408.

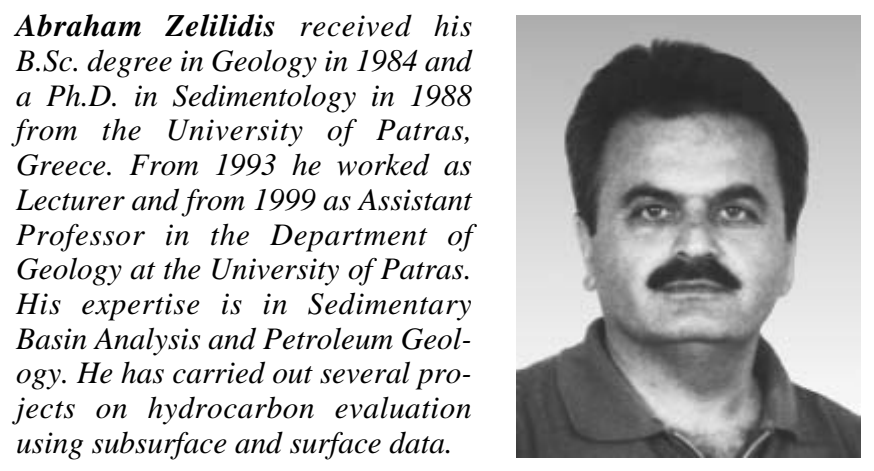

